\title{
Global Mobility beyond Traditional Assignments - A Review on Flexpatriates and International Business Travellers
}

\author{
Padmini Jayasekara \\ Department of Human Resource Management \\ University of Sri Jayewardenepura, Gangodawila, Nugegoda
}

\begin{abstract}
:
The purpose of this article is to explore the concept of flexpatriates and international business travellers (FIBT) and related issues of FIBTs. Finally, the outcome of the article is enriched by presenting a policy oriented conceptual model for managerial concern to resolve such issues of FIBSs. A literature-based data compilation was done to develop this model. The model mainly outlines the necessity of giving strategic policy orientation on managing FIBTs by considering several supportive channels: organizational support and social support for both assignees and families.
\end{abstract}

\section{Key Terms: Non-traditional assignments, Flexpatriates, International Business Travellers}

\section{Introduction}

Throughout the past few decades global staffing is one of the main challenges of multinational companies (Torbiorn, 1999; Mayerhofer et al., 2004). Researchers in the field thus progressively have encountered new challenges pertinent to the manageability of global work force ensuring competitive advantages. An international assignment typically begins when an employee is sent abroad to work in an organization's foreign business plant. This employee is called an international assignee and the given task is called an international assignment. MNCs are using multiple ways and multiple types of alternatives to conduct their international businesses. There are a number of non-traditional types of international assignments held by different names. As in literature, non-traditional expatriates include short-term assignees, flexpatriates and international business travelers (Shaffe et al, 2012; Suutari et al, 2013; Welch et al., 2003). Flexpatriates are often appointed on a commuter, rotational or contractual assignment basis (Mayerhofer et al, 2004, Welch et al., 2003). This paper aims to discuss flexpatriates and international business travelers. Because relatively little is known about the aforesaid empirical and theoretical knowledge gap for further researches is kept.

Thus the purposes of this article can be stated as:

1. To explain meaning, strengths and limitations of each assignment type

2. To discuss the issues of flexpatriates and international business travellers

3. To present a conceptual framework for future managerial implications

\section{Literature Review}

\subsection{Commuter Assignment}

A special arrangement where the assignees commute or travel from home country to a place of work in another country usually on a weekly or bi-weekly basis is known as commuters (Mayerhofer et al., 2004a; Collings et al., 2007). These types of assignees complete international assignments by commuting rather than relocating themselves in host countries. During the tenure, mostly they have work responsibilities in both home and host countries (Deloitte, 2013). Normally, their family remains in the home country. Allowances and other benefits are entitled for these assignees. Commuter assignments may be used to serve short-term and long-term assignment to address a specific business problem and business needs. Commuter assignees usually remain on the home-country payroll and spend defined periods (weeks or months) abroad, commuting home on a regular basis. 


\subsection{Rotational Assignment}

This type occurs when the employee spends, successively, a short period of time working overseas, followed by a period at home (Collings et al., 2007). International assignees travel to the host country to work for a period of time and then return to the home country to take a break before traveling to the host country for another working period and so on. Diplomats and employees belonging to Foreign Service categories represent this assignment type. Ex: Sri Lankan Foreign Service officers are assigned a three-year service period in a country and it is necessary for them to work in the Ministry of Foreign Affairs before fly to another country.

\subsection{Contractual Assignees}

This type is used when an international project requires specific skills. Contractual employees are used to fill the necessities of specific skills vital to an international project. Time duration lay between 6-12 months (Collings et al., 2007). The nationality may be PCNs in many cases.

\subsection{International Business Travellers/ Frequent fliers}

The increase in globalization has led to an increase in international business travellers assignments. These are employees who take business travel as an essential component of their job. These assignees travel daily or bi-weekly to other countries (Welch and Worm, 2006). These assignees are also known as frequent fliers. Also, international business travelers are posted up to a few weeks but not exceeding 3 months (DeFrank et $a l, 2000)$. In some cases, it lasts for one or two months and are called as extended business travellers (Herod, 2008). Associated cost of air fare, hotel, meals and other incidental expenses in the same way they do domestically are reimbursed. These assignees are mostly handled by respective line managers of the parent organization instead of IHRM department.

Table 1. Advantages and disadvantages of FIBTs

\begin{tabular}{|c|c|}
\hline \multicolumn{2}{|c|}{ Flexpatriates } \\
\hline Advantages & Disadvantages \\
\hline $\begin{array}{l}\text { - Accelerate international learning } \\
\text { capacities of employees } \\
\text { - Easy life management with minimum } \\
\text { barriers } \\
\text { - Children's education undisturbed } \\
\text { - Spouse's career unaffected } \\
\text { - No premature return } \\
\text { - Flexibility } \\
\text { - Develop global networks } \\
\text { - Facilitate informal knowledge sharing }\end{array}$ & $\begin{array}{l}\text { - Work permit issues } \\
\text { - Liable for tax and social security in } \\
\text { both countries } \\
\text { - Issues surrounding pension } \\
\text { provision, driving licenses and } \\
\text { healthcare. } \\
\text { - Difficult to meet the developmental } \\
\text { objectives of the assignment. } \\
\text { - Difficult to develop good } \\
\text { relationships with HCNs }\end{array}$ \\
\hline \multicolumn{2}{|c|}{ International Business Traveler/ Frequent fliers } \\
\hline Advantages & Disadvantages \\
\hline $\begin{array}{l}\text { - Flexibility } \\
\text { - Simplicity } \\
\text { - Cost effectiveness } \\
\text { - No difficulties of out of sight and out of } \\
\text { mind situation }\end{array}$ & $\begin{array}{l}\text { - Frequent short trips lead to many } \\
\text { family issues } \\
\text { - Higher travel stress } \\
\text { - Health issues } \\
\text { - Safety issues }\end{array}$ \\
\hline
\end{tabular}

Sources: Scullion and Collings, 2006., Mayerhofer et al, 2004., Tahvanainen et al, 2005., Collings et al. 2007., DeFrank et al, 2000., Sen et al, 2006., Wittig-Berman \& Beutel, 2009.

\subsection{Purposes of FIBTs Assignments}

As in literature, these assignments are regularly used for different purposes: implementing specific assignments and knowledge transfer, maintaining relationships, troubleshooting or problem-solving, and 
gaining international experience (Mohd and Nankervis, 2015) trouble-shooting, problem solving and other technical issues (Meyskens et al., 2009 ). Mayerhofer et al. (2004) found that an Austrian MNE used flexpatriates for skill transfer and management development, while Tahvanainen et al. (2005) found Finnish MNEs used non-traditional assignees mainly for skill transfer and problem-solving, managerial control and management development. PricewaterhouseCoopers (2000) surveyed and found them as for the knowledge transfer, performance monitoring and control technology transfer or consulting. Welch et al. (2007) recorded purposes of non-traditional assignments as career development and training of local personnel and knowledge transfer. Meanwhile, technical support, consulting, training, solving problems, supervise projects, and management control are also some purposes of non-traditional assignees including FIBTs (Kang, and Shen, 2016).

\subsection{Reasons for Popularizing FIBTs Assignments}

Many researchers intensively attending to understand the complexities around expatriate assignments (Hervey et al., 2009) as cost involvement, dual career problem, and adjustment problems more critically lesser retuned on investment (ROI) contribution compared to direct and indirect cost associated, urge towards for portfolio of assignments as a result. But authors don't see perfect complimentary possibility of these two types for each other because of the differences of each assignment in terms of purposes and expected and actual outcomes. Therefore, awareness on how and at what conditions the alternatives are suitable is required to discuss further. However substitutability of non-traditional assignments for expatriation is a matter of both home and host country and some of the factors are pressing as solutions for existing problems (Push factors) and others are pull factors taking advantage of non-traditional assignments themselves.

Table 2: Drivers of using non-traditional assignments

\begin{tabular}{|l|l|}
\hline \multirow{4}{*}{ Push Factors } & \multicolumn{1}{c|}{ Home Country } \\
\cline { 2 - 3 } & Developing global talent leaders \\
Business changes \\
Advanced technology \\
Developments in transport connections \\
& Improvements in broadband data connection \\
& Lower distance to host country \\
& Global Market development \\
& Nature of task \\
& High cost over expatriation \\
& Managerial unwillingness to accept long term assignments \\
& Unavailability of staff \\
\hline \multirow{5}{*}{ Pull Factors } & Highly Volatile Cost Country \\
\cline { 2 - 3 } & Legal regulations over temporary migration \\
& High caliber local staff \\
& Advanced technology \\
& Market development \\
\hline
\end{tabular}

Sources: Mayerhofer et al., (2012), Baker and Ciuk, (2014), Puchmüller and Fischlmayr, (2016)

\section{Issues of FIBTs Assignments}

The following discussion provides an overview of issues under three major themes. Those are organizational related issues, individual related issues, and host country related issues which are highly necessary to consider at any policy decisions especially around FIBTs.

\subsection{Organizational related Issues}

Growing trend of using non-traditional international assignments is a great administrative burden in some areas for international HR managers, (Colling et al, 2007). Ex: particularly relation to tax, unaccompanied 
families, and work permit issues, social security, visa and legal requirements of the various conditions. As in a survey by PricewaterhouseCoopers (2005), majority of MNCs follow a single policy for both traditional expatriate assignments and non-transitional assignments which are around 50\% of respondent MNCs. More specifically, Kang and Shen, (2016) revealed the absence of formal recruitment and selection policies for non-traditional Korean expatriates in China. This finding was consistent with the findings of Western studies (Suutari et al., 2013) as well. However, such informal ad hoc-solutions can be positive in the short term, but may lead to issues in the attractiveness, development and retention of the long-term potential benefits of an experienced talent work team. Thru evaluation and judgment over the competence of the assignees, it is observed that there is a lack due to rushed decisions taken within very short notice. As Suutari et al. (2013) suggested lack of formal recruitment and selection have a negative impact on short-term expatriates and the company as a whole in many ways.

Provision for attending a pre-departure training is subject to many factors like cultural distance, time duration of the assignment, available time gap to departure as proved according to Conroy et al (2018). Generally, performance appraisals for non-traditional expatriates are similar to home country practices (Suutari et al., 2013), even home country evaluates hold a lack of awareness on contextual conditions of the performance in host location but evaluation by both the subsidiary and headquarters are more beneficial (Kang, and Shen, 2016) as proven in the Korean context. Raters included immediate supervisors in headquarters and managers responsible for projects in local subsidiaries. Compensation is another IHRM issue pertaining to FIBTs. The pay is managed in line with home country base pay including tax free allowances on daily basis, cost of living allowance and sometimes including hardship allowance. However, assignments for more than one week, travel allowance, meal allowances and a free company car during their stay were normally allowed. Absence of such support causes to increase stress and lead to poor adjustment and performance of the assignees (Beaverstock et al., 2010; DeFrank et al., 2000).

\subsection{Individual issues}

More significantly family/spouse issues were the most ignored by MNEs in the recruitment and selection of non-traditional expatriates (Kang, and Shen, 2016). A survey done by ORC Worldwide (2003, 2005) revealed that conditions of family attendant of short-term assignees are very poor. Family issues including employment rights for spouses, definition of family unit may be still a problem in many countries. For example child minders or grandparents are often not recognized as part of the family unit (OECD, 2004). On the other hand, assignees with a spouse holding different nationality face more problems. However, separation of a family is a big problem for both assignee and family members (DeFrank et al., 2000; Mayerhofer et al., 2004), separation from family and family's well-being (Espino et al., 2002; Westman et al., 2008). Irrespective to the type of international assignment, time spent away from home is normally a difficult aspect, because the higher psychic cost over loneliness, guilt over missing family activities like birthday parties, wedding anniversaries etc. In addition to them, separation from family and consequent work-family conflict (Starr and Currie, 2009), and travel stress, anxiety, depression and sexual difficulties (Sutherland and Flin, 1989) are also issues that the assignees suffer a lot from. However, Westman et al. (2009a, b) suggested that these consequences are moderated by quality of the familial relationships, age of the children, spousal support and frequency and length of travel in which bring new direction to streamlining selection criteria of these assignees.

\subsection{Host country related issues}

FIBTs are also bound with double tax liabilities in both countries over same income. In the case of business travelers and flexpatriates who may travel to many different countries will be probably protected. For the assignees that move abroad for less than six months without family, the biggest obstacles are delay in obtaining visa and work permits. In the case of a frequent business traveler assignment, getting work permit may be a problem even though there are some countries that allow work without work permit. Mostly it's dependent on the duration of assignment and the nature of the business due to undertake. For an example international business travelers sent on project basis that are intended to stay for few weeks, but if the project extended, it will raise serious problems with immigration authorities over work permit and tax payment. A survey on Global Mobility Program management survey of 377 multinationals conducted by ORC and Deloitte in 2007, $38.5 \%$ of companies have not taken any action regarding visa and income tax regulations for short-term assignment and flexpatriates assignments (Herod, 2008). At the condition where 
these non-traditional assignments are entitles other than business meetings, training or conference attendance a work permit will be an essential matter.

\section{A Framework for Managerial Implication}

For the FIMTs, these issues are critically important in designing appropriate policies and practices to support both assignees and the organization. As in the literature (Demel and Mayrhofer, 2010; Mayerhofer, Schmidt, Hartmann and Bendl, 2011), separate policies for non-traditional assignments are needed. The following framework is proposed as a necessity of paying attention on: organizational support for FIBTs through a range of IHRM practices, organizational support for family members, and getting use of FIBTs' social network assistance through family and other companions.

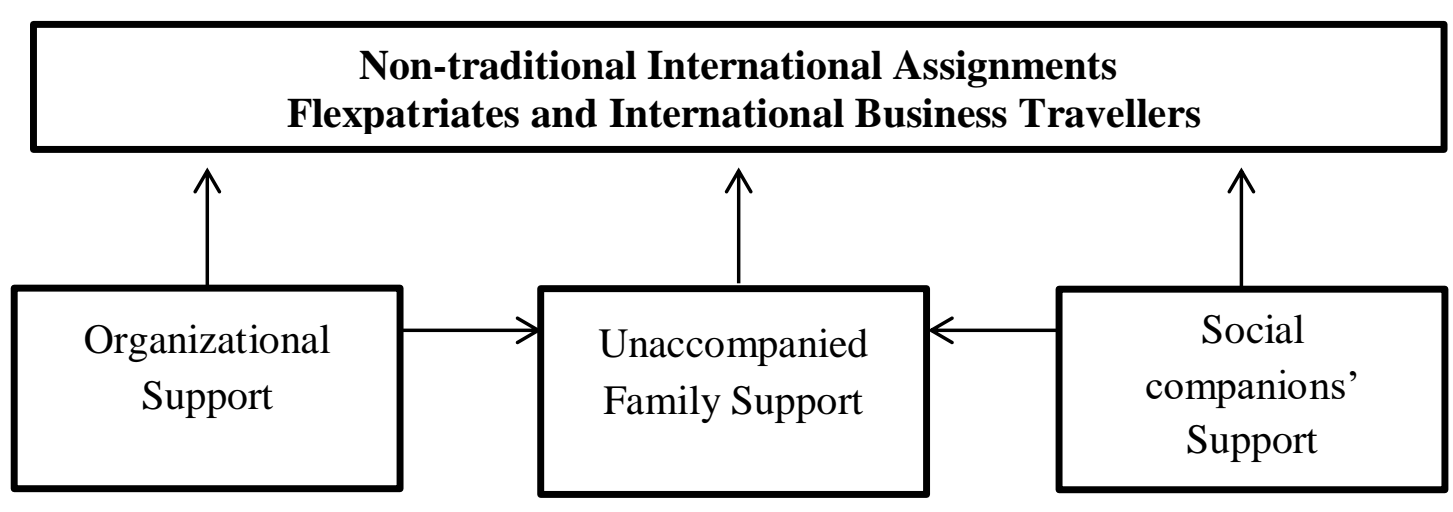

As globalization is increasingly setting new rules, regulations and norms, it is quite visible that there is a necessity of solid, competitive international human resource management policies and procedures to get successful business results through proper usage of FIBTs. On this changing nature of assignments, MNCs need to give considerable attention on developing policies on tailor made methods because the uniqueness of each type will have implications for localization policy and practices. Unfortunately written policies over expatriation also are not in a good position as Fenwick (2004) it was less than $50 \%$ and $71 \%$ as PricewaterhouseCooper (2005). More remarkably 50\% of companies showed that single policy would cover both long term and short- term assignments. At the same time there is more favorable future as $80 \%$ of respondents realized the importance of separate policies for both. Standard form of IHRM policies and procedures would not enhance the proper usage of alternative international assignments. It essentially should reflect the associated differences of each assignment type by taking case-by-case analysis (Colling et al. 2007). However absence of such polices over alternative assignments is largely left with employees and their families.

Short-term and commuter assignments and other types of assignments are mostly done on ad hoc basis highly relying on assignees' technical competence. In terms of determining productivity and effectiveness of the NTIAs, cross-cultural awareness of the assignees is quite impotent and thus in the selection process, behavioral and cognitive flexibility are needed to measure. As Mayerforer et al, (2004) argued nontraditional international assignees are suitable for certain category of employee as single or younger people who bound less with family responsibilities and bear less cynic cost over relocation. At the same time changing demographic pattern of assignees around the world also is important on policy design. If the international work group consists of younger people sometimes their experiences and family ties may be less but may be a good source of staffing in FIBTs. Unless FIBTs married and spouses status has clear implication and need to consider a balance of home life responsibilities together with travel frequency, airfares, flight allowances and home leave trips are important.

The necessity of pre-departure training for expatriate assignments is well documented by researchers but there is lesser degree over alternative types of assignments. Available time for adjustment in the new setting is comparatively less for short-term, international business travelers and flexpatriates minimizing cultural shock. This training requirement is needed to be considered by both HR and line mangers (Collings et al. 2005). Rigor of the pre-departure training should be tailor made for each assignment and pre-identification of pool of candidates for international assignments can minimize the training cost and companies can practice this as an ongoing process. Mostly short-term assignments are in accordance with very short notice 
(Conroy et al, 2018) and not enough time to conduct that kind of training program and thus normally with less experienced assignees access non work social groups through personal contacts to get some information and assistance. However, the time duration hope to stay in foreign country, nature of the given task, trainers' foreign experiences, degree of interaction with employees in subsidiary and host nationality should be considered deciding pre-departure training program.

PE management issues also problematic on deciding evaluation criteria, who should do the evaluation are need to be define clearly. Still MNCs are not in a correct track to identify the requirements in a satisfactory level. In most cases assignees by themselves take proactive role in their adjustment and use their personal networks to meet the challenges due to absence of proper training.

Deciding compensation package for assignees who perform different tasks, through different time duration is so critical because of the sensitivity of the issue. HR support systems should address the problem around these types of assignments, introducing support package for assignees as well as families too. Among the nontraditional assignments, in most cases comparatively, short- term assignees allow to take their family with them. Policy makers must take in to account the matter allowing the employees to substitute visits from spouse, children for trips home. Another important issue comes under the assignee' home country health care plan, and insurance coverage is so friendly one with international coverage. As such companies must be careful to provide an additional provision to cover medical emergencies. In most cases for these types of non-traditional international assignees which are not entitled for hardship allowances because of unaccompanied condition of family members but considering the criteria of isolation, crime and culture, inadequate sanitation and disease, poor medical and hospital facilities, unavailability of consumer goods, lack of educational facilities, lack of poor community facilities, political instability, crime, and harassment (Herod, 2008) policy makers should hummer in terms of deciding the package.

Thereby, extended organizational support for unaccompanied families ensures good support to the spouse/father or mother of the assignee who has left the country. This is mainly because they create the good organization's image in the eyes of family members, developing psychological bond. On the other hand, research has shown that when employees feel that their families are supported by their organizations, and feel valued by their organization, they tend to develop identification with and a moral obligation to the organization (Shen and Zhu, 2011).

In addition to this, some of the researchers have conducted to investigate how the organizational supportive aspect is necessary for FIBTs family members through the extension of information giving support, emotional support and instrumental support. (Puchmüller, and Fischlmayr, 2016., Demel and Mayrhofer, 2010; Fischlmayr and Puchmüller, 2016). In most cases family relocation does not occur, as in the literature bases of Collings et al., (2007) or survey data by Brewster et al., (2001) or longitudinal case study (Starr et $a l ., 2009)$. But they viewed the available psychic cost over separation of the family even for a short period of time. Organizational related support practices are beyond the employment contract but still facilitate for a strong foundation on psychological bond between FIBTs and the organization, e.g coordination of schooling for children, childcare, or concierge services (Demel, 2010). The norms of reciprocity allow expatriates to respond favorably to the organization in many ways. Increased understanding for assignees personal life and family background, may consequently lead to have positive outcomes like, increased organizational commitment (Thompson et al., 2004), improved job performance, lower turnover, lower turnover-intention (Jayasekara and Takahashi, 2014) and higher life satisfaction (Haar and Roche, 2010; Mills et al., 2014). Thus, founding correct organizational supportive executions towards FIBTs' families should be a goal of the parent organizations.

Social network support is the availability and quality of helping relationships (Leavy, 1983) through multiple sources namely colleagues, roommates, religious groups, associations of fellow townsmen, superiors, friends and other NTIAs: co-workers, supervisors, and friends are frequently asserted (Caligiuri et al, 2002; Kraimer et al, 2001). Such channels are supportive to keep them in a good mental condition through helping to access work related information before departure, help for residential arrangements and their willingness to extend their helping hand to the rest of the family members (caring older parents and 
support on their health issues), assurance of continuing assignees' responsibilities and obligations on social activities during his or her absent period (LaRocco et al.1980., Puchmüller and Fischlmayr, 2016).

Family support for FIBTs is highly remarkable. In common, disruption of child-father/mother relationship can have great influence on child development which always works badly for assignees mentality. Absence from daily life will lead to miss some events in the family life (e.g. birthday party, children's school events, unplanned visit to the doctors make a burden for the assignees' family when spouse/ father/mother are regularly abroad, spend less time with handling childcare and household chores (Fischlmayr and KollingerSanter, 2014). This can have a positive impact on the FIBTs motivation, ambition, and performance in both work and family environments (Demel, 2010).

However, there is no clear one-size-fits-all solution, but business needs, assignment location, the average length of assignments, and the assignee's nationalities and purpose of assignment should be considered in identifying the appropriate policies (Jayasekara, 2020, Herod, 2008). Organizational given supports for unaccompanied families emphasized the necessity for continuity of the welfare as a matter of organizational labour-management policy.

\section{Conclusion}

Non-traditional international assignments are an important consideration of many MNCs who are contingent on a globally mobile workforce. This article contributes to understanding two non-traditional international assignments: flexpatriates and international business travelers. More specifically, some of the related issues as most profoundly affecting their assignment success and some facts to incorporate in organizational policy framework also have explained. In concluding, the researcher believes that the necessity of more close observation on each and every type of FIBTs to consider all implications around all types of assignments. This may ensure development of effective and efficient global oriented talent management framework for both traditional and nontraditional assignees.

\section{References}

[1] Baker, C and Ciuk, S. (2014), "Keeping the family side ticking along” An exploratory study of the work-family interface in the experiences of rotational assignees and frequent business travellers, Journal of Global Mobility, Vol. 3, No. 2, 2015 pp. 137-154.

[2] Beaverstock, J.V., Derudder, B., Faulconbridge, J. and Witlox, F. (2010), International Business Travel in The Global Economy, Ashgate Publishing Ltd, Surrey

[3] Brookfield Global Relocation Services (2012), Global Relocation Trends: 2012 Survey Report, Brookfield Global Relocation Services, Woolridge, IL.

[4] Brookfield Global Relocation Services (2013), Global Relocation Trends: 2013 Survey Report, Brookfield Global Relocation Services, Woolridge, IL.

[5] Brookfield Global Relocation Services (2014), Global Relocation Trends: 2014 Survey Report, Brookfield Global Relocation Services, Woolridge, IL.

[6] Brookfield Global Relocation Services. (2012), Global Relocation Trends, available from http://espritgloballearning.com/wp-content/uploads/2011/03/2012-Brookfield-Global-Relo cationsTrends-Survey.pdf

[7] Collings, D. G., Scullion, H., \& Morley, M. J. (2007), Changing patterns of global staffing in the multinational enterprise: Challenges to the conventional expatriate assignment and emerging alternatives. Journal of World Business, 42, 198-213.

[8] Conroy, K.M, Mc., Donnell A, and Holzlitner, K. (2018), A race against time: Training and support for short-term international assignments. Journal of Global Mobility, Vol 6, No3/4, 299-315.

[9] DeFrank, R.S., Konopaske, R. and Ivancevich, J.M. (2000), "Executive travel stress: perils of the road warrior", Academy of Management Executive, Vol. 14 No. 2, pp. 58-71.

[10] Demel, B. (2010), "Karrieren von Expatriates und Flexpatriates: Eine qualitative Studie europaweit tätiger ManagerInnen aus Österreich (Careers of expatriates and flexpatriates: a qualitative study of European-wide working managers from Austria)", Rainer Hampp Verlag, Mering.

[11] Demel, B. and Mayrhofer, W. (2010), "Frequent business travelers across Europe: career aspirations and implications", Thunderbird International Business Review, Vol. 52 No. 3, pp. 301-311. 
[12] Espino, C.M., Sundstrom, S.M., Frick, H.L., Jacobs, M. and Peters, M. (2002), "International business travel: impact on families and travellers", Occupational and Environmental Medicine, Vol. 59 No. 5, pp. 309-322.

[13] Evans P, Pucik P, Barssoux (2002), The Gloabla challenge: Framework for international human resource management, New York, Mcgraw-Hill.

[14] Fenwick, M. (2004), On international assignment: Is expatriation the only way to go? Asia Pacific Journal of Human Resources, Vol. 42 No.3, 365-377.

[15] Fischlmayr, I.C. and Kollinger-Santer, I. (2014), "Female frequent flyers: how women travelling internationally handle their work/life balance", in Hutchings, K. and Michailova,S.(Eds), ResearchHandbookonWomeninInternationalManagement,EdwardElgarPublishingLimited, Cheltenham, pp. 47-70.

[16] Global relocation trends 2003/2004 survey report. Retrieved March 10, (2014), from http://www.nftc.org/default/hr/GRTS\%202003-4.pdf

[17] Haar, J.M. and Roche, M. A. (2010), "Family supportive organization perceptions and employee outcomes: the mediating effects of life satisfaction", The International Journal of Human Resource Management, Vol. 21 No. 7, pp. 999-1014.

[18] Herod R. (2008), Short-term International Assignments: Implementing effective policies, Society of Human Resource Management, USA

[19] Jayasekara, P. (2020b), Short-term international assignments and their performances: A conceptual framework for future researchers, International Journal of Research in Human Resource Management, 2020; Vol. 2No. 2: 19-26.

[20] Kang, H. Y., \& Shen, J. (2013), International recruitment and selection practices of South Korean multinationals in China. The International Journal of Human Resource Management, 24, 33253342.

[21] Kang, H., and Shen, J. (2016), Not all expatriates are the same: non-traditional South Korean expatriates in China, The International Journal of Human Resource Management, 28(13):1-24

[22] Mayerhofer, H., Hartmann, C. L., \& Herbert, A. (2004), Career management issues for flexpatriate international staff. Thunderbird International Business Review, 46(6), 647-666.

[23] Mayerhofer, H., Hartmann, L. C., Michelitsch-Riedl, G., \& Kollinger, I. (2004), Flexpatriate assignments: a neglected issue in global staffing, The International Journal of Human Resource Management, 15(8), 1371 - 1389.

[24] Mayerhofer, H., Schmidt, A., Hartmann, L., \& Bendl, R. (2011), Recognising diversity in managing work life issues of flexpatriates. Equality, Diversity and Inclusion: An International Journal, 30, 589-609.

[25] Salleh1, N.M and Nankervis, A. (2015), Non-Traditional Expatriate Assignments in the Asia-Pacific: Characteristics \& Challenges, Human Resource Management Research 2015, 5(1): 1-11 DOI: 10.5923/j.hrmr.20150501.01

[26] Mills, M.J., Matthews, R.A., Henning, J.B. and Woo, V. A. (2014), "Family-supportive organizations and supervisors: how do they influence employee outcomes and for whom?", The International Journal of Human Resource Management, Vol. 25 No. 12, pp. 1763-1785.

[27] Puchmüller, K and Fischlmayr, I. (2016), Support for female international business travellers in dualcareer families. Journal of Global Mobility, Vol. 5 No. 1, 2017 pp. 22-42

[28] Shaffer, M. A., Kraimer, M. L., Chen, Y. P., \& Bolino, M. C. (2012), Choices, challenges, and career consequences of global work experiences: A review and future agenda. Journal of Management, 38, $1282-1327$.

[29] Shen, J., \& Lang, B. (2009), Cross-cultural training and its impact on expatriate performance in Australian MNEs. Human Resource Development International, 12, 371-386.

[30] Stahl, G. K., Miller, E. L., \& Tung, R. L. (2002), Toward the boundaryless career: A closer look at the expatriate career concept and the perceived implications of an international assignment. Journal of World Business, 37, 216-227.

[31] Starr, T. L., \& Currie, G. (2009), 'Out of sight but still in the picture': Short-term international assignments and the influential role of family. The International Journal of Human Resource Management, 20, 1421-1438. 
[32] Sutherland, K.M. and Flin, R.H. (1989), "Stress at sea: a review of working conditions in the offshore oil and fishing industries", Work and Stress, Vol. 3 No. 3, pp. 269-285.

[33] Suutari, V., Brewster, C., Riusala, K., \& Syrjäkari, S. (2013), Managing non-standard international experience: Evidence from a Finnish company. Journal of Global Mobility: The Home of Expatriate Management Research, 1, 118-138.

[34] Tahvanainen, M., Welch, D., \& Worm, V. (2005), Implications of short-term international assignments. European Management Journal, 23, 663-673.

[35] Thompson, C.A., Jahn, E.W., Kopelman, R.E. and Prottas, D.J. (2004), "Perceived organizational family support: a longitudinal and multilevel analysis”, Journal of Manageria,l Issues, Vol. 16 No. 4, pp. 545-565.

[36] Welch, D. E., \& Worm, V. (2006), International business travellers: A challenge for IHRM. In G. K. Stahl \& I. Björkman (Eds.), Handbook of research in international human resource management (pp. 283-301). C

[37] Welch, D. E., Welch, L. S., \& Worm, V. (2007), The international business traveller: A neglected but strategic human resource. The International Journal of Human Resource Management, 18, 173183.

[38] Westman, M., Etzion, D. and Chen, S. (2009a), "Crossover of positive experiences from business travelers to their spouses", Journal of Managerial Psychology, Vol. 24 No. 3, pp. 269-284.

[39] Westman, M., Etzion, D. and Chen, S. (2009b), “Are business trips a respite?", in Perrewe, P., Ganster, D. and Sonnentag, S. (Eds), Research in Occupational Stress and Well-being, Vol. 7, JAI Press/Elsevier Science, pp. 167-204.

[40] Westman, M., Etzion, D. and Gortler, E. (2008), "International business travels and the work family interface: A longitudinal study", Journal of Occupational and Organizational Psychology, Vol. 81 No. 3, pp. 459-480. 